\title{
Modernity, THE COMMONS AND CAPITALISM George Skouras*
}

\begin{abstract}
The modern way of life and reflected in modern political philosophy is directed by capitalist activity of both commodities and persons. Entities that do not have commodity value are worthless to the capitalist enterprise, regardless of any intrinsic value in themselves. Modernity is capitalist modernity. Modernity has given preference for objects/commodities over persons. This paper will argue for openingup the landscape for alternative experiences to capitalism, as an attempt to move away from the capitalist enterprise. That is, be able to provide open space for people to use other than the buying and selling of commodities---where the commodification process breaks down and opens-up spaces for alternative experiences besides the capitalist experience. In other words, this work will attempt to serve as critique of Enlightenment philosophical discourse---that is, serve as a critique of the Age of Enlightenment serving as the foundational head of modernism---a plea for the rebellion against the quantification and mathematization of reality under modernist and industrial societies. It will use the modern landscape as the first effort to break free from the capitalist enterprise.
\end{abstract}

\section{KEYWORDS}

Modernity; Enlightenment Philosophical Discourse; Commons Revised and Revisited; Land Use Policy Management; Rationalization of Space-Time under the Corporatist/Capitalist World

\section{CONTENTS}

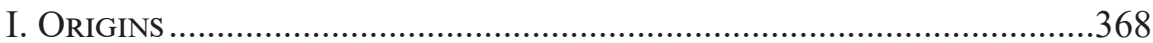

II. The Commons Revised and Revisited ..........................................369

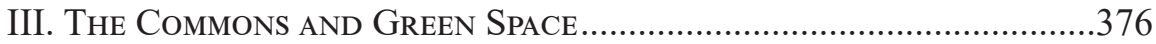

IV. Modernity and Land Use Policy Modifications .........................378

V. The Capitalist Culture and Theory of Justice ............................382

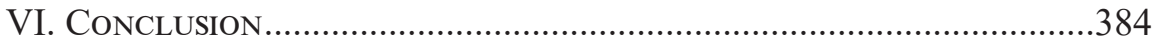

* Institutionally Unaffiliated and Independent Scholar 


\section{ORIGINS}

One ancient mode, or should I say primitive mode of shelter, was to use the trees as the home space. Upon reaching the ground floor and starting to walk on twos, the human animal began to seek other modes of shelter such as caves and other natural barriers or enclaves that served as good sources for home-making and the protection from the elements or other natural dangers that the human animal faced in the primitive world. ${ }^{1}$ With the dawn of modern civilization, with the coming of the Agricultural Age, agricultural communities started to put down more robust and artificial settlements, as opposed to the use of caves, in taking charge of the landscape. Agricultural society found it useful to erect long lasting fixed houses, and also serving as the anchoring the human animal down to a fixed landscape, as opposed to the previous phase of humanity, the Hunter-Gatherer stage, where the human animal roamed large and great distances in pursuit of the necessities of life.

Let us start from the beginning, beyond our primitivism stage of existence, the laying of the foundation of the modern age---the Enlightenment and the arrival of Industrialization---unanchored the human animal in the pursuit of capital and investments wherever they existed. In other words, the human animal was set free from its anchorage to the land. And, so, capital replaced land as the key ingredient in modernist times. This new age also brought in a new political and social world, just as steep as the primitive ages in jumping from a Hunter-Gatherer stage to the Agricultural Age. What has become clear, over the last few centuries, is the realization that the human animal is not tamable and in fact a very deadly animal. Liberalism, conservatism, socialism, existentialism, fascism and other major political philosophies miss one thing: that our species is a deadly animal---a bloodsoaked animal, even among the most generous reading of history. We, as a species, were bred long before we fell off the trees, walked on twos, etc. upon the milk of violence and bloodshed. Why? We can blame "Nature." It layered on top of a lizard brain (a reptilian brain), an ape (mammalian) brain. Primates containing within their evolutionary history the amphibian and the reptilian structures of previous ions of biological and evolutionary development---'nature' not discarding previous structures completely but modifying them for further use. That is, previous ions of biological development, before the mammal makes an appearance on planet earth, nature was busy developing the process and modifications in the survival of biological entities on planet earth. Nature (the evolutionary process) used the patterns of previous species in layering on mammalian/primate brain on top of amphibian/reptilian brain. This mix of different species contained, in our species' brain structure, has bred our species, sort to speak, for violence and bloodshed.

An aggressive posture, with regard, to using other animals as food, even though our species evolved from pre-humanoid tree animals that took most of its supplies from leafy greens and fruit to becoming an omnivore. Even though the human animal is neither a pure vegetarian or carnivore animal, it can use either food supply to get its required calories per day---had our species been a pure carnivore, slaughter would probably would have been much more ingrained in our genes; the

Cyril Aydon, A Brief History of Mankind: 150,000 Years of Human History (2009) (2007); Hannah Holmes, A Natural History of Our Lives (Atlantic Books, 2010) (2008). 
contemplation, of the human animal as a pure carnivore, is too frightful to fathom--which, of course, would translate into greater bloodshed. Omnivore animals are less deadly and dangerous than carnivore animals. ${ }^{2}$ Also, the human animal, like all mammals, is a territorial animal and prepared to defend its territory to the death from invaders. ${ }^{3}$

How does the modern human animal allocate space under industrial and postindustrial societies? We know the history of agricultural societies and the methods they used in the allocation of land. They worked the land and lived off the land. What is clear is that, with the rise of capital and technological development, land has become a second-class citizen to the rising tide of capital formation and capital accumulation. The Common Law began to accommodate the needs of industry and business during the early part of the $19^{\text {th }}$ century. According to the eminent legal historian, Morton J. Horwitz: "[M]ill acts adopted in a large number of states and territories on the model of the Massachusetts law were, more than any legal measure, crucial in dethroning landed property from the supreme position it had occupied in the eighteenth century world view, and ultimately, in transforming real estate into just another cash-valued commodity."

As the Common Law was being transformed, in the United States to accommodate business and industry, the Enclosure movement ${ }^{5}$ in England was approaching its final solution in enclosing common land for private use. It was of some concern as to how those that depended on use of the Commons to graze their animals, collect wood to heat their homes, etc. as to how they can continue to exist on the land? The usual refrain was that they can be packed into cities with the hope of landing an industrial job. But at the same time people caught in the industrialization process, under capitalist conditions, also need alternatives to take back a dimension of control of-themselves and for-themselves from the ordering of the capitalist process, and make sure that the landscape is utilized for the benefit of the whole community rather than monopolized under a few privileged hands. Since people cannot return to the land, as before the capitalist/industrial transformation of the economy, it should not also mean that they are completely helpless and enslaved within the capitalist system of boom and bust cycles. ${ }^{6}$

\section{The Commons Revised And Revisited}

How is the word 'Commons' being used here? The idea of the Commons has a long history. The Commons harkens back to medieval English history. It refers to a manor and its commons as a way of life for the English for well over a thousand years before the rise of capitalism and the acceleration of the Enclosure movement and finally its extinction by the mid- $19^{\text {th }}$ century. We are defining a Commons, as a piece of property surrounding a manor or a point of centrality for any given

2 Desmond Morris, The Naked Ape: A Zoologist's Study of the Human Animal (1967).

3 Holmes, supra note 1, at 126-56.

4 Morton J. Horowitz, The Transformation of American Law, 1780-1860 48 (1977).

5 J. A. Yelling, Common Field And Enclosure in England, 1450-1850 (1977).

6 Joseph E. Stiglitz, The Roaring Nineties 3-28 (2003); Naomi Klein, Shock Doctrine: The Rise of Disaster CAPITAlism (2007). 
community, that can be used by the locals for their own purposes and ends. That is, in demarcating a modern Commons, or the bringing- back of a Commons model, based on medieval English traditions, would require certain modifications, in-light of the eclipsing of the Agricultural age, by the Industrial age. A modern definition of a Commons can simple be of any central point, in given communities, that leaves surrounding area open for use by the commoners, or put more modernly, the people of those communities. The Commons is a piece of property that is open to all in the community for their use. It is not public property, in the sense that it is open for the whole world to use but restricted for the use and benefit of the locals living in that community. However, the modern Commons, instead of the Commons surrounding the Manor House, as in ancient times, the modern Commons surrounds the City Hall or Town Hall or Central House, so designated as ideal for establishing the Commons, and such central entity will govern, support, and execute the will of the community to have and establish their particular type of Commons. A much broader definition of the Commons also includes what is referred to as CommonPool $^{7}$ resources.

The commons is the cultural and natural resources accessible to all members of a society, including natural materials such as air, water, and a habitable earth. These resources are held in common, not owned privately. Commons can also be understood as natural resources that groups of people (communities, user groups) manage for individual and collective benefit. Characteristically, this involves a variety of informal norms and values (social practice) employed for a governance mechanism. Commons can be also defined as a social practice of governing a resource not by state or market but by a community of users that self-governs the resource through institutions that it creates. ${ }^{8}$

Under modern scientific analysis for setting up a Commons, it would be illogical, unproductive, and inefficient to operate because fewer people controlling the land can yield better results and better profits for the few hands that control the land. So, why involve the many in the community to dabble on communal land when they can be used elsewhere in the system? Whether it is land-use management for best output per acre of land or the management of Common-Pool resources, the long knives are out, as to who sets the policy in such matters? Is it the democratically elected leaders of a given community or the elites and property owners? In the case of Common-Pool resource management, is it the responsibility of the Federal government and Global States to take leadership in the setting of use policy or the Large Corporations and other Industrial interests in an age of globalization? Much

7 Modern Common-Pool resources encompasses a very wide range of issues beyond the scope of this article such as Environmental issues which deal with a much larger chunk of the modern economy than land-use issues. Nevertheless, learning to deal with Common-Pool resources becomes essential for cooperative efforts to reduce the impact of the human animal on planet earth and its natural resources.

8 Soutrik Basu, Joost Jongerden \& Guido Ruivenkamp, Development of the Drought Tolerant Variety Sahbhagi Dhan: Exploring the Concepts Commons and Community Building, 11(1) Int'L. J. Commons 144 (2017); Elinor Ostrom, Governing the Commons; The Evolution of Institution for Collective Action (1990). 
ink has been spilt as to the feasibility of establishing such Common-Pool entities. ${ }^{9}$ That is, modern scholars and theorists have spent a great deal of time and energy debating and fighting over the feasibility, desirability, or efficiency of CommonPool resources to accomplish ends best left to private hands and private markets. These theorists point to many problems and paradoxes that emerge once CommonPool resources become available for distribution. ${ }^{10}$ And suggest that efficiency principles do away with these feudal and unnecessary byways in the modern age. Modern economic theory suggests that the privatization process will yield the best result, much superior result over Common-Pool issues, than spreading out the process to communities controlling their environment. To some degree they may be right, but control of one's environment (air, water, land) are communal entities that cannot be privatized without leaving the many to suffer the contamination of their environment under the efficient control of the few for their interests.

In the case of Land-Use matters, involving the setting up a Commons, market economists would be horrified at such a messy prospect. According to capitalists, these communal paradoxes can disappear and be vanquished by introducing the principles of private property ownership of land. Private property can better accomplish a clean-up of environment and contamination issues by markets. The point of efficiency is one thing, the point of sharing communal property effectively is another. To prevent anarchy in dealing with Commons or Common Pool Resource problems requires a strong central authority, granted by the commoners, in the monitoring and enforcement of rules, for usage of common land. The centrality of the matter is ground zero, local centrality, rather than national centrality, since those closest to the ground are the most knowledgeable as to how best to deal with the Commons. By mathematization and strict scientific analysis is not the best way to deal with Commons issues but by those with hands-on-the-ground, in midst of the ebb and flow of communities, that rise and fall over time and require the workings and justice systems of the commons work and re-worked to make the necessary adjustments, as the flow of life is not stationary but dynamic and must be continuously adjust with proper and fair solutions as demanded on the ground. It is an issue of dynamic phenomenology. ${ }^{11}$

During the early history of the United States, the unbounded frontier ${ }^{12}$ rendered the Commons as unnecessary due to the abundance of cheap land. In the United States, the idea of a Commons was not embraced as was the case with England. Hence, America never developed a legal system ${ }^{13}$ that duly respected the rights to a Commons. Although the American Constitution does not give absolute rights to property owners, it gives them sufficient rights and minimal obligations with regard to property ownership. ${ }^{14}$

\footnotetext{
Elinor Ostrom, The Drama of the Commons (Thomas Dietz et al. eds., 2002).

10 Garret Hardin, The Tragedy of the Commons, 162 Scr.1243 (1968).

11 Edmund Husserl, The Crisis of European Sciences and Transcendental Phenomenology: An Introduction of Phenomenological Philosophy (David Carr trans., 1970) ( 1936); Michael Ermarth, Wilhelm Dilthey: The Critique of HistoricAl REASON (1981 paperback ed.)(1978).

12 Frederick Jackson Turner, The Frontier in American History (2006).

13 Horowitz, supra note 4, at 31-62.

14 U.S. Const. amend. V.
} 
In the United States, land use was primarily left to the States and Local governmental entities to deal with, mostly local governments. And this is the proper process, that land use be dealt with primarily by the locals, but that does not absolve the Federal \& State governments of not providing any resources or assistance to the local communities to better monitor, enforce, distribute, and resolve local land use matters. That is, local governments do not have adequate resources to properly and fairly deal with land use issues. Should Commons property start popping up around communities all over the United States, it will require all hands onboard-Federal, State, and Local - to make the new system work. Of course, this becomes essential, especially the role of the Federal government, in taking the lead in matters involving and dealing with wide scale Common-Pool issues such as the environment, oceans, and climate change.

The early days of America and up to the close of the $19^{\text {th }}$ century, America had abundant land for the taking. The major issue was the development of that land. The unbounded frontier of America provided the space to make the obligations of property holders as minimal as possible, since any serious obligations could provoke them to pick up stakes and move elsewhere. But since the frontier has long been closed, there needs to be tighter regulations of land use and the need for national policies, giving lawmakers stronger tools to police the landscape and public domain space from the encroachment of private property.

Land use management has basically fallen to private hands, essentially the most powerful interests. Currently, the public property/public space has been rendered as second class property under capitalism via the growth of the corporation. With minimal restrains by the public sector over the corporate interests, due to the influence exerted by Big Business in the USA and under the political and philosophical dogma that free markets, individualism and private property ownership is the gold standard of life, public interests have become subservient to private interests. Although the use of anti-trust legislation exists, it is weak and not strong enough to curb or contain the corporate structure. ${ }^{15}$ This has led to the disparagement of public property because the growth and size of corporations becomes unlimited as the growth and size of government becomes limited. "[T]he United States has long-standing and powerful institutions, but they have been subject to political decay. Government institutions that are supposed to serve public purposes have been captured by powerful private interests, such that democratic majorities have a difficult time asserting their control." ${ }^{16}$ So, that all those people, who lack private property are cast as secondclass citizens to those that own private property in the capitalist system. ${ }^{17}$ The need of a Commons essentially becomes the life-blood of all those disposed by private interests. And Land Use becomes the tool for people to take control of their local political, economic, and social destiny unless they want to serve as the leftovers or final remains of the private interests and ebb and flow of market economics.

15 George E. Garvey \& Gerald J. Garvey, Law and Economic Growth: Antitrust, Regulation and the American Growth System (ann. ed. 1990); Edwin Mansfield, Monopoly Power and Economic Performance: Problems of the Modern Economy (4th ed. 1978); John E. Kwoka, JR. \& Laurence J. White, The Antitrust Revolution: The Role of Economics (2d ed. 1994).

16 Francis Fukuyama, Political Order and Political Decay: From the Industrial Revolution to the Globalization of Democracy 7 (2014).

17 Howard Zinn, A People's History of the United States, 1492- Present (1995) (1980). 
As indicated earlier, the problems and paradoxes of the Commons is not a science problem ${ }^{18}$ but a social and humanitarian problem. ${ }^{19}$ The ideology and philosophy of transforming social and humanistic issues into science issues has been to neutralize, sterilize, and de-vitalize the problems. The methodology of science is positivistic ${ }^{20}$ and can work in many natural process and domains of inquiry. However, the procedures of science are not the appropriate tools in the study of human interactions---the dynamics of the everyday. The problem of the Commons cannot be studied in the laboratory, but by trial and error over countless situational moments that work for a given arrangement or timeframe but then become dynamic and liquid as interactions between people become fluid. It has more to do with a phenomenology of the moment in day to day fluid dynamics that renders the external observer nugatory as the parties or communities come to an understanding of their own situation and their own times. The rationalization process and scientific endeavor of the Enlightenment and positivistic enterprise is not the be all and end all marker of human understanding and knowledge.

The concept of the Commons and community have suffered under capitalism if not eliminated altogether. If the concept of public space is to be well regarded, from its low regard in American history, it is imperative that public institutions be respected and strengthened to serve as a "countervailing" force to privateers and profiteers such as the modern corporations. John Kenneth Galbraith has made the case, in his 1952 book, American Capitalism, that a capitalist system, left unchecked by countervailing forces, will tend towards the monopolization of resources. ${ }^{21}$ However, Derber points out the countervailing power is not always generated by existing ruling power.

Countervailing power, as Galbraith describes, is power exercised by unions, governments, consumers, suppliers, and competitors to keep corporations in check. Galbraith painted the Gilded Age as an era of tragically weak countervailing power, and his analysis offers the tools to recognize today's unnerving parallels. The flaw in his argument comes in his faith that great power inevitably creates great countervailing power--a tenant at odds with Lord Acton's famous view that absolute power creates absolute corruption, and one that blinded him and other great midcentury liberals to key parts of the American story.22

18 Garrett Hardin, The Tragedy of the Commons, 162 SCI. 1243-48 (1968); Ronald Coase, The Problem of Social Cost, 3 J.L. Econ. 1-44 (1960); Russell Hardin, Collective Action (1982); Mancur Olson, The Logic of Collective Action: Public Goods AND THE TheORY OF Groups (1965); Ostrom, supra note 9.

19 Husserl, supra note 11; ERMARTH, supra note 11

20 A. J. Ayer, Language, Truth, and Logic (Penguin Books 2001) (1936); Friedrich Stadler, The Vienna Circle: Studies in the Origins, Development,and Influence of Logical Empiricism (2015). Auguste Comte, Introduction to Positive Philosophy (Frederick Ferre trans., 1988).

21 John Kenneth Galbraith, American Capitalism: The Concept of Countervailing Power (2012) (1952); John Kenneth Galbraith, The New Industrial State (3d rev. ed., 1978); Immanuel Wallerstein, After Liberalism (1995); Alan Trachtenberg, THE INCORPORATION OF AMERICA (25th ann. ed. 2007).

22 Charles Derber, Corporation Nation 31 (1998). 
Capitalist conditions under corporate rule help concentrate power in specific locations and points of leverage, such as banking, to control the distribution, not only of capital, but the labor power and community resources available to the locals. Land, that once served as a leverage point, has become secondary to the monopolization of the economy by giant corporations. So, local communities cannot take charge of their localities and metropolitan regions, if the local/state authorities are paired up with corporations that dictate what land uses are permissible and what will interfere with the function of modern business transactions and corporate rule. That is, the latitude and broadness granted to the locals to construct and run their Commons and communities depends on a strong government to keep Big Businesses at bay. Otherwise, the fusion of Big Business and the government cut the interests of the locals for self-determination and expression in having something as the dirt under their feet to stand on.

The modern Commons must be able to determine: Whatever is grown on the Commons/or taken off the Commons is for one's own benefit or the local community, but not for national or international sale. What is grown/or taken from the Commons is for local benefit only.

1) Commons property is not private nor public property. Should one want to make use of the Commons, then so be it. Since the Commons is not private property, one cannot reserve the property or keep the property upon leaving the community. In other words, Commons property does not travel with the user.

2) The Commons is open space for the community, and under governmental assistance and monitoring for fairness, in its distribution and uses becomes essential for preventing anarchy on the Commons. Liberal ${ }^{23}$ theories of justice and fairness such as those modeled on the locality principles of Elster ${ }^{24}$ working under conditions of scarcity or the rationality principles of Rawls ${ }^{25}$ may be rich in theory but poor in practice. Communitarian principles are better suited for the cooperative control of the Commons than theories of liberty, individuality, and market power.

3) The addition, revision, re-positioning of the Commons, as was the case in traditional land use matters, also needs re-imagining under Industrial and Post-Industrial societies where land use is simple unavailable for the locals, but the locals are nevertheless free to designate other entities as Commons in the sense of providing them the traditional rewards of feeding their livestock or gathering fire wood to heat their homes off the Commons in the old days---sort of modern day equivalents to traditional Commons that can be used for the re-training and re-tooling of the community members to best cope with modernist conditions brought about by unfettered capitalism.

By overcoming the commodification process, in the turning over of commodities, in keeping labor employed and tied to its sustainability levels, there needs to be a

23 Richard E. Flathman, Toward a Liberalism (1989).

24 Jon Elster, Local Justice: How Institutions Allocate Scarce Goods and NeCESSARY BURDENS (1992).

25 John Rawls, A Theory of Justice (rev. ed. 1999) (1971). 
re-evaluation of values that reverses the current capitalist process of production. This reversal of values will produce commodities not simply to sustain life but to enhance life. That is, the human animal cannot afford to invest its time and space (conventionally measured) to the production of commodities while in the process devaluing that animal. The commodity in capitalist system is raised to a God while the human animal remains mortal. As indicated above, the commodity takes up space and time for its production, and consequently, is/exists in time and space--nothing is instantaneous in the production realm. The human animal also takes up space/time conventionally understood, but also lives an existence of its thrownnessin-the-world which is not the physicist's time but within a conceptual existence of its own making. ${ }^{26}$

Liberalism in the United States has come to mean the right to buy stuff, regardless of environmental damage because the whole economy depends on making and selling stuff. ${ }^{27}$ The making and selling of stuff as the precondition and condition for capitalism leads to large swaths of the human animal engaged in these enterprises---that is, one's life depends on engaging in these activities. The re-establishment of a Commons becomes, in some small way, an alternative way of life free from this capitalist way of life and enterprise. The less stuff made, the less stuff circulates which means the more people become unemployed or remain unemployed. ${ }^{28}$

How has it come about that America is enslaved in the factory system of production psychology? And the factory system mentality pervades (even though manufacturing jobs have left the USA in droves); maybe, it is because such a system raised the United States from a reginal power to a world power; in that it first gave Americans domination over North America and later domination of the globe. ${ }^{29}$ It nevertheless dominates the landscape and American psyche, as one looks all around the country seeing the dying, closed, or rotting square and rectangular building wasting away under the elements. What is it about this country, the USA, which believes order, efficiency, and money are the tickets to a better economy, more goods and services, better production and distribution that lead to a better society in general? It seemed during the 1990s that technology was going to be our savior, as manufacturing jobs disappeared. It was thought technology would step up, to take the unemployed off the streets, as the production line took the workers off the streets and turned them into efficient cogs in the production cycle at an earlier time

26 Martin Heidegger, Being and Time (John Macquarrie \& Edward Robinson trans., 1962) (1927); HusSERL, supra note 11; Existential and phenomenological philosophies that situate the human animal in-the-world with at-hand tools in the making and unmaking its environment---not only the current human made environmental-existential crisis with regard to climate change and planet contamination but an existential crisis of the human animal thrown-into-the-world (nature) and asked to live and become a commodity for use and disposal like a plastic bag; in other words a plastic world with plastic people at the ready for disposal.

27 Olivier Zunz, Making America Corporate, 1870-920 (1990).

28 Robert McChesney \& John Nichols, People Get Ready: The Fight Against a Jobless Economy and a Citizenless Democracy (2016); Alec Ross, The Industries OF THE FUtURe (2016).

29 Joshua B. Freeman, American Empire: The Rise of a Global Power, the Democratic Revolution at Home, 1945-2000 (2012). 
in America ${ }^{30}$ It has come to equate work with life itself. In other words, work is not a means to a good life but life itself. Of course, under conditions of scarcity it is easy to believe that a piece bread, fresh water, a piece of meat or other edible foodstuff can be equated with life itself. That is, one cannot have life itself unless people can have food, water, and shelter. But a minimal life is not a full life.

\section{The Commons And Green Space}

One such alternative to capitalist production is to nurture the Commons (and other green spaces) and to grant people rights to the land for their immediate use. An earlier generation of Americans, the Progressives and Populists, at the close of the $19^{\text {th }}$ and early $20^{\text {th }}$ centuries, attempted to wrest control from Big Business interests with some success. ${ }^{31}$ That is, this early generation of workers and farmers were beginning to see the difference between themselves and the corporate interests and bravely fought back, although ultimately they were defeated by the capitalists. What eventually became clear is that whole communities could be wiped out, washed away, or erased away with every boom and bust of the capitalist cycle. ${ }^{32}$ The drawing from the Commons the material and use of land as needed becomes an alternative way of being/existence to the capitalist universe, and also allow for the rise of communities that are not completely dependent on the business cycle. The hope being that the human animal can fall back to the land during bust cycles and does not need to roam large distances (as was the case in pre-civilized times), during the Hunter and Gatherer stage. The moving and dislocation of Americans, in search of work or due to the loss of work in the pursuit of jobs, has become a way of life under modernist conditions. And by focusing on localities attempt to feed workers from locally grown food supplies and thereby cut down the further contamination of the environment, with lessening the transportation of food from

30 Joseph E. Stiglitz, The Roaring Nineties: A New History of the World's Most Prosperous Decade (2003); See also, John Milton Cooper, Pivotal Decades: The United States 1900-1920 132-45 (2003).

31 Charles Derber, Regime Change Begins at Home: Freeing America from CORPORATE RULE 29-30 (2004):

Despite its awesome power, this first corporate regime forced a radical challenge by the Populists, fiery farmers and plain-spoken people from the heartland who created the People's Party in 1892, captured the Democratic Party in 1896, and launched one of the country's most politics of regime change. They proclaimed in 1892 that corporations were being used "enslave and impoverish the people. Corporate feudality has taken the place of chattel slavery." While the Populists melted away with the 1896 presidential defeat of their candidate, William Jennings Bryan, they helped give rise to the reform movement of the Progressive Era under the "trust-buster," President Theodore Roosevelt. In 1907, Roosevelt called for "the effective and thorough-going supervision by the National Government of all the operations of the big interstate business concerns," a direct challenge to the "free market" regime discourse of the robber barons.

32 Thomas Piketty, Capital in the Twenty-First Century (2013); Naomi Klein, Shock Doctrine: The Rise of Disaster Capitalism; Norman Birnbaum, The Crisis of Industrial Society (Oxford, UK: Oxford University Press, 1970) (1969). 
long distances and save spoilage costs and the need to pump food with preservatives that are coming from far-away places.

To take the human animal into an artificial world is to remove that animal from its natural settings and primitivism that it has existed since the dawn of civilization. Once again, the animal becomes free to gather the resources it needs for survival from the land, in the location of its existence, rather than roaming the land as in HunterGatherer times. It looks like capitalism has brought forth a new Hunter-Gatherer age by sending the worker to roam the globe to find, produce, and utilize capital in the most efficient manner possible. Although establishing a Commons, in and of itself, is insufficient to provide the human animal complete safety and control over the boom and bust cycles of capitalism, it at least takes the first step in the integration of that animal to its community. Most likely a modern Commons, in the utilization of land, will only go so far and no further in meeting all the needs of modern human in the Industrial Age. That is, whether a Commons is used as a garden, re-training centers, retooling and repurposing skills centers, such as job re-training centers, is a determination for the locals to decide how best to setup and run their Commons. During the medieval times sheep grazing and wood collection might make a good use of the Commons, but during modern times, skill and re-tooling one's skills, may make better sense. The capitalist cycle uproots the workers from their localities, so that their labor power can be used wherever the systems needs them. The urban and suburban geographical spaces along with demographic shifts ebb and flow with each capitalist boom and bust cycle. ${ }^{33}$ Making and remaking population shifts in the pursuit of urban or suburban spaces that will best satisfy their needs in the modern metropolis centers. There is no anchorage to the American way of life outside the plasticity of the now or the nowness society. In short, the American community is a plastic community---just as disposable as a plastic bag after a single use. ${ }^{34}$

The return of the Commons (the attempt to bring back the Commons) is one small step towards returning the animal to the garden. Once again as a reminder of its biological connection with its primitive aspects and as a functional alternative to the mathematization and commodification of space and time..$^{35}$ Under capitalist conditions, the most important things are things of production. In the emerging Green-space world, the emphasis needs to be allowing the human animal back to an uncontaminated garden, that is environmentally fit for nurturing the community and thereby the individual and makes communion with the soil and earth alternative realities to the producing world for sale or the production and commodification of the world in the Industrial and Post-Industrial Age. The re-shifting of industrial policy towards workable communities rather than industrial pits of production could go a long way in beginning the process of creating living spaces ${ }^{36}$ Even though the

33 Bruce Katz \& Robert E. Long, Redefining Urban and Suburban America: EVIDENCE FROM CENSUS 2000, Vols. 1, 2 \& 3 (2003, 2005, 2006).

34 Charles Derber, Corporation Nation (1998); Maurice R. Stein, The Eclipse of Community: An Interpretation of American Studies (1960 (exp. ed. 1972) (1960); Raymond Jackson Wilson, In Quest of Community: Social Philosophy in the United States 1860-920 (1968).

35 Alfred W. Crosby, The Measure of Reality: Quantification and Western Society, 1250-600 (1997).

36 Edward K. Spann, The New Metropolis: New York City, 1840-57 (1981); Chalmers Johnson, The Industrial Policy Debate (1984). 
modernist industrial city, as directed by capitalism today, may be too centralized, concentrated, and disposable with every boom and bust cycle, the demanding of extracting natural resources from other weaker nations around the globe speaks of the selfishness of the powerful nations need to control the weaker countries via the exploitation of their natural resources, and hence the need to maintain formal or informal empires. ${ }^{37}$

It should not mean that cities of the future must be based on the factory model of production. And cities, like Detroit or other cities that have been depopulated due to the bust cycles of capitalism, are given a second chance of revival, by re-engineering themselves, by dedicating more open space/green space/environmentally friendly space for the greening of their cities and greater space availability for the Commons. ${ }^{38}$ Of course, people re-tooling themselves to live a full life in communities that value them should be the goal rather than functioning as production tools for Big Business. But there should be no limit to the imagination, as to what type of Commons communities ask for, as long as the Commons principles are not violated.

\section{Modernity and Land Use Policy Modifications}

The problem of property acquisition, distribution, rationalization, and use is directly connected with the modern age via its connection to the Age of Reason/Age of Science, Enlightenment, and Post-Enlightenment ${ }^{39}$ of property being an extension of the human self as it has been rationalized into the cultural and civilizational mode of existence. In other words, a given civilizational development sets the horizons as to what to expect (expectations) and how to react to property/land. In the case of the Agricultural Age, land ownership, use, and control are critical to the survival of the individual, family, and community that worked the land and fed off the land. The Age of Reason is the starting point of Modernism---the mathematization/ quantification of reality (key to modernity). ${ }^{40}$ "For Platonism, the real had a more or less perfect methexis in the ideal. This afforded ancient geometry possibilities of a primitive application to reality. [But] through Galileo's mathematization of nature, nature itself is idealized under the guidance of the new mathematics; nature itself becomes---to express it in a modern way---a mathematical manifold [Mannigfaltigkeit]." 41

37 Eric J. Hobsbawn, Industry and Empire: From 1750 to the Present (1990) (1968).

38 Maurice Dobb, Studies in the Development of Capitalism (1947); Talcott Parsons, The Structure of Social Action, 1 (1968) (1937).

39 Karl Polanyi, The Great Transformation: The Political and Economic Origins of Our Time (1957); Sigmund Freud, Civilization and Its Discontents (reprint ed.1989) ( 1930); Andre Groz, Critique of Economic Reason (1989); Edward A. Purcell, Jr., The Crisis of Democratic Theory: Scientific Naturalism \& the Problem of Value (1973).

40 Husserl, supra note 11; Reinhard Bendix, Work and Authority in Industry: IDEOlOgies OF MANAGEMENT IN THE COURSE OF INDUSTRIALIZATION (1963) (1956); David Beetham, Max Weber and the Theory of Modern Politics (2d ed., 1985) (1974).

41 Husserl, supra note 11, at 23. 
In other words, the accountancy of everything of value and the discounting of the environmental aspects to life such as air, water and land that can be contaminated at will because they cannot be privatized and put into the accounting books. It is assumed under capitalist conditions that everything can be parceled, chopped up and distributed to the highest bidder. Natural entities like the oceans, rivers, lakes, mountains, air, etc., unappropriated property that are used by the public are there for the taking or contamination simply as externalities of doing business.

Because under modern conditions, it is assumed that the human animal can be individualized and marked off or cut off from nature from which it came and become an appendage of the machine---just as in previous ages it was an appendage of the plough. Capitalism has not freed the human animal from the modern plough, just substituted modern forms of ploughs that the animal can be yoked to. If we know anything about the Age of Reason, it was an effort to expel religion, superstition, and mysticism from the day to day world, and replace the medieval world with common sense, science, mathematics, and the questioning of one's presuppositions before leaping off the ground.

Modern societies have transformed the natural landscape in pursuit of beliefs of efficiency and productivity in the use of the landscape, under a capitalist ideology. The prioritization of the use of the landscape for the commodification process has eclipsed other modes of non-capitalist Being. Prior ages had their own transformative belief of the landscape to meet the needs of those living at the time. Under capitalist ideology, the solution to human problems being the-to-at-hand animal $^{42}$ making efficient use of space and natural resources in the transformation of these resources for commodity distribution within a market system. This transformation goes along with the mathematization of space-time to accommodate this new distribution of resources to the masses. The measurement of all aspects of living and existence becomes the calling card for modern being. In other words, the human animal is under the clock from the second he/she is thrown into the world, to be managed, trained, and conditioned for the tasks that will earn him/her a living. Whether the idea of work is a modern concept arriving with the Industrial Revolution or something human animals engage in from time immemorial has been reviewed and examined..$^{43}$ It nevertheless has been rationalized and adapted by the modern world as the marker of productivity and life itself for billions of people around the globe.

The bottom line being that work along with technological assistance can assist human power to bring nature under our control and dominion. These technological developments also tie the human animal and relate that animal to artificially created spaces and environments---through the efficient use of technology, that create the space or bubble for in-space living. That is, human animals create artificial spaces along a given landscape. The impact of that artificial space may be minimal or can be rather an extensive overhaul to meet the real or artificial needs of those making the change to the landscape---by way of extreme example, think of the artificial conditions that must be created to put the human animal into space once it leaves its natural environment, earth. No

\footnotetext{
42 HeIDEGGER, supra note 26.

43 Groz, supra note 39.
} 
animal can live on the landscape of the moon without drastic reconstructions and reconfigurations to simulate earth conditions. During earlier times, the human animal lacking in how-to knowledge and technological tools was only able to make minimal modifications to the landscape. Aliens landing at the site thousands of years later would not be able to see the remains or the footprints left behind by the human animal in primitive spaces using primitive tools. But with greater technological prowess, it becomes real and very dangerous that a life-blood animal, like a human, with limited use and control of rational thinking and actions can devastate the natural landscape in an instant. Of course, the underlying presumption, under the Age of Reason/Enlightenment Age, that human reason can do away with its primitive belief structures and come up with efficient strategies to maximize the good for all. Of course today, with a more nuanced view of the rational capabilities of natural animals, with a mixture of amphibian, reptilian, and mammalian brain structures, sits uneasily besides the beliefs of the Enlightenment generation of intellectuals.

Our solution to capitalism and the rationalization of land use will be: we can start by attempting to create de-rationalized landscape/land-space--- decommodification and de-glorification of markets and the transformation of living, from one of acquiring products and commodities, to one that is one (in unity) with the land that sustains us. ${ }^{44}$ Land is not a product for use, a tool-at-hand, but a resource constituting a landscape horizon for the emerging life there, both human life and/ or other animal life. All animals have a right to the land. There is no inherent right to private ownership of the land or earth itself. The land cannot be made for sale unless it has been improved, Locke. ${ }^{45}$

Those that have land ownership have a privilege to use the land from the State, but not the right to the ownership of the land itself. That is, the ultimate control of the land always rests with the State, but the State grants the owner certain rights and privileges to the land that has been improved upon by its legal owner.

44 Polanyi, supra note 39.

45 John Locke, The Second Treatise of Government 18-30 (1980) (1690); ("Whether we consider natural reason, which tells us, that man once born, have a right to their preservation, and consequently to meat and drink, and such other things as nature affords for their subsistence: or revelation, which gives us an account of those grants made of the world to Adam, and to Noah, and his sons, it is very clear, that God, as king David says, Psal. cxv. 16. has given the earth to the children of men; given it to mankind in common.") Id. at 18; ("Though the earth, and all inferior creatures, be common to all men, yet every man has a property in his own person: this nobody has a right to but himself. The labour of his body, and the work of his hands, we may say, are properly his. Whatsoever then he removes out of the state that nature hath provided, and left it in, he hath mixed his labour, and joined to it that is his own, and thereby makes it his property. It being by him removed from the common state nature hath placed it in, it has by his labour something annexed to it, that excludes the common right of other men: for this labour being unquestionable property of the labourer, no man but he can have a right to what that is once joined to, at least where there is enough, and as good, left in common for others. Id. at 19) ("It is true, in land that is common in England, or any other country, where there is plenty of people under government, who have money and commerce, no one can inclose or appropriate any part, without the consent of all his fellow-commoners; because this left common by compact, i.e., by the law of the land, which is not to be violated. And though it be common, in respect of some men, it is not so to all mankind; but is the joint property of this country or this parish.). Id. at 22 
However, the title owner to the land only holds provisional or conditional control, until the State has a need either to take the land from the private owner for public use via the takings clause or via eminent domain processes, as per the specification of the $5^{\text {th }}$ Amendment to the U.S. Constitution. ${ }^{46}$

If human animals do not have capital resources to sustain themselves, then they should have recourse to return to the land itself. Since the land is a natural resource, all creatures can claim a space on it, be it humanoid or not. Should that landscape become privatized or monopolized, as is the case under modernist/ capitalist conditions, then life under that landscape becomes a privilege of the owners. Land cannot be bought or sold like any other commodity. However, during early in the $19^{\text {th }}$ century, Morton Horwitz, in his major work, The Transformation of American Law 1780-1860, tells us how land was being transformed into capital. "As a result, the mill acts adopted in a large number of states and territories on the model of Massachusetts law were, more than any other legal measure, crucial in dethroning landed property from its supreme position it had occupied in the eighteenth century world view, and ultimately, in transforming real estate into just another cash-valued commodity." ${ }^{47}$

According to modern Western political philosophy, the land is tied up with the sovereign or the sovereign has the power to decide how land is to be used and divided amongst the populace. However, if the land is foundational to life, then the sovereign, ${ }^{48}$ having the power to control the land, has also the power of life and death over the creatures and animals that exist on the land. This philosophy of land ownership by the sovereign is not universal but derived from common law ${ }^{49}$ at different historical points different theories prevailed as to who has ultimate control of the land. The tumultuous nature of the $20^{\text {th }}$ century, turned upside down, work space, land-use space, and intellectual space, for the working classes, industrial classes and managerial classes across the board. ${ }^{50}$

46 George Skouras, Takings Law and the Supreme Court: Judicial Oversight of the Regulatory State's Acquisition, Use, and Control of Private Property (2000 paperback ed.) (1998)); George Skouras, On the Formation of the American Corporate State: The Fuller Supreme Court, 1888-1910 J. JuRIs. 37 (2011).

47 Morton J. Horwitz, The Transformation of American Law, 1780-1860 47-48 (1979).

48 Thomas Hobbes, Leviathan (Penguin Books, 1968 paperback ed.) ( 1651); so, the two British philosophers, (Hobbes and Locke) serving as foundational heads of the Enlightenment, along with the coming of the French Revolution and French intellectuals, were important sources in shaping the American Republic; of course local American intellectuals/politicians such as John Adams and Thomas Jefferson were susceptible to the ideas of reason.

49 Edward S. Corwin, The "Higher Law" Background of American Constitutional LAw 26 ( 1955) (1928)(“common law embodied right reason furnished from the fourteenth century its chief claim to be regarded as higher law...the right reason to which the maxims of higher law on the Continent were addressed was always the right reason invoked by Cicero, it was the right reason of all men. The right reason which lies at the basis of the common law, on the other hand, was from the beginning judicial right reason.").

50 Michael Harrington, The Accidental Century (1966) (1965); John Dunn, Democracy: A History (2005). 
So, what is to be done ${ }^{51}$ To break free human labor and human life from the commodification process, to break the bonds that give the commodity superstatus and human animal supporting status, in its making and unmaking, requires a transformation of the link between labor and commodity. One way to regain a measure of freedom from the commodification process is through the allocation of Commons land to every metropolitan area and city. There should not be any city of any size that does not have a traditional Commons where possible or a Virtual Commons to meet modern needs.

\section{The Capitalist Culture and Theory of Justice}

Now, if life is beyond the materiality of existence, it is not to say the obverse is true; that it must be spirituality that is the necessary element to living life. No, materiality is the condition of life but to appreciate life requires reflection, self-reflection and otherness-reflection, to fit into nature properly. Those that find spirit or mystery in nature should not be pushed aside in the name of materialism. The proper natural fit can only be obtained when each individual is thrown into a particular civilizational mold but starts to build themselves as experiential and cognitive beings during the course of their lives---not according to the dicta of the given, but the dicta of the possible within the restraints of the civilizational mold they find themselves in--that is, the civilization one is thrown into becomes the horizon the possible because no one can escape their civilization they are thrown into, that is to say one does not get to pick the times one is born into. ${ }^{52}$

What is the American way to materialism? Produce it and they will buy it; build it and they will come. The American creed, as it has developed over the span of the Industrial Revolution, and only found in embryonic form prior to the Civil War, is that materialism is the be-all and end-all of the American system and the American way of life. This belief in materialism is in a sense a throwback to more primitive conditions of life, in that the acquisition of land, property, and objects were the very fabric of life itself. One would have assumed that machines and robots would have eased the burdens of humans, and in supporting a civilization that transcended the more barbarous activities forced upon human animals for their existence on planet earth in earlier times and would have progressed to non-materialist development of self. Yes, there have been many preachers over the centuries advocated for the development of the spirit rather than materialist concerns. In a sense, all religions preach such a message, but none of the previous civilizations could offer alternatives to the barbarous conditions the human animal faced on earth---so it was basically an empty message if humanity could do nothing about its daily barbarous activity.

Of course, modern day tele-preachers, with their tele-churches have eroded any semblance to the early Calvinist Protestantism. But there is something in the Protestant spirit that, unlike other religions, frees the individual to master the world

${ }_{51}$ Elinor Ostrom, James Walker\& Roy. Gardner, Covenants With and Without the Sword: Self-Governance Is Possible, 40 Am.PoL.Sci.Rev. 309-17 (1992).

52 Freud, supra note 39; Polanyi, supra note 44; Madam Sarup, An Introductory Guide to Post-Structuralism and Post-Modernism, (2d ed. 1993); Max Weber, Economy and Society: An Outline of Interpretive Sociology (Guenther Roth \& Claus Wittich trans., 1978) (1922). 
in the glory of God or as a manifestation of God's will on earth. Of course, this phenomenon of Calvinistic Protestantism was noticed early on by Max Weber. ${ }^{53}$ But there is something of this Calvinistic Protestantism that preaches production for its own sake is good and to hold back production is a sin. So the original Protestantism although praised production did not simply advocate that production must destroy what was produced to keep up with the boom and bust cycles of capitalism---what Schumpeter referred to creative destruction of goods, ${ }^{54}$ so that a new cycle of production can begin and not have idle hands---that is, idle hands are the devil's tools for mischief and moral decay.

The necessity for the quick destruction of products is the key to modern society renewing itself by the employment of what otherwise would be idle hands--the unemployed being thrown off the line if the production line ceased to move forward. The assembly line, in the making of and assembly of cheap goods, that could be used once and discarded as quickly as possible to help continue to feed the workers on the line. That is, in order to sustain and maintain the capitalist system of production, nature itself must be destroyed in order to produce enough commodities to keep the workers at their tasks and hence curb any from revolting or revolution.

Life for production, not life for living. Globalization and free trade are good for the capitalists but bad for the workers. It has become unfortunate that the trend for re-locating work to the cheapest places on the globe, now more than 150 years in the making, has not been able to be reversed or contained, to give the masses a better chance at life because it is justified and sold under principles of rationality, efficiency, modernity, and progress. It might be progress for the top $1 \%$ but a nightmare for the remaining $99 \% .^{55}$

What does this mean? The support of industry at the expense of family and community. The idea of bringing back the Commons can serve to open-up space to alternative experiences outside the commodification experience.

Liberals, like John Rawls, have the belief that fairness and justice can be restored under a veil of ignorance in the distribution of talent and resources. $\mathrm{He}$ belongs to the social contract tradition. ${ }^{56}$ Rawls derives his social contract from liberal philosophy. It is a hopeful philosophy that posits rationality in a favorable light and that the power of rationality can overcome the power of instinct in the human animal. From the start we have a 'non-starter', what makes him believe that the human species is a "rational" animal? Aristotelian logic in not dispositive of this subject matter. Has he not read Freud ${ }^{57}$ or other modern psychologists? Has he not read history that suggests the that human animal is knee deep in blood? What if our species is a non-rational and violent animal, roaming the planet, as it has for ages looking for food and shelter as it has from the days in has fallen off the trees?

Rawls must have been aware that there is no period in human history that has been able to escape battle, war, killings, bloodshed, etc. for any extended

\footnotetext{
53 Max Weber, The Protestant Ethic and the Spirit of Capitalism ( Peter Baehr \& Gordon C. Wells trans., 2002) (1905).

54 Joseph A. Schumpeter, Capitalism, Socialism and Democracy (15th ed. 2008); Ernest Mandel, Late Capitalism 377-407 (Joris De Bres trans., 1978) ( 1972).

55 Ray Ginger, Age of Excess: American Life from the End of Reconstruction to WORLD WAR I (1965); KLEIN, supra note 32.

56 John Rawls, A Theory of Justice (rev. ed. 1999) (1971).

$57 \quad$ FREUD, supra note 39.
} 
period of time, and such a bipedal animal would use all available weapons in its toolbox, at any historical time, to carry forward killing on a small scale or in mass. As I indicated at the start of this paper, I suppose we can blame 'Nature' for this disposition; if we can ask 'Nature' why it has infused the human animal with such a deadly aspect/nature: 'Nature', in your infinite wisdom, why did you bring forth a species like the human being via a method of layering neo-cortex on top of more primitive and earlier brain, on top the brain stem rather than start afresh in the construction of the human animal? I fear 'Nature' will respond with silence. The way evolution operates is not by discarding previous patterns that survived but building on them; if a fish or a reptile could prove resilient and survive, why not add additional brain on top of existing brain? The vertebrate pattern did no start afresh but built up from the invertebrate pattern of previous ions of development.

Clearly, Rawls starts from a utopian proposition. Equality and freedom are metaphysical concepts. No two animals are identical. So, no two animals can biologically be compared as identical, but only similar. Similarity is not identity. The only equality that can exists is a metaphysical equality or mathematical equality. The liberty Rawls speaks of is only historically contingent liberty and hence has no universality. Currently, in America the corporation rules,${ }^{58}$ and individualism is a concept of a bygone era in America, but political philosophy theorists and other social science theorists cling on to it as the key to the good life. Yet America is corporate run, not individualistically run.

\section{CONCLUSION}

The major conclusion derived here is that open space must remain open within city, suburban, and rural settings. The control of space for market use has displaced animal living for the accommodation of transactional living---living from moment to moment in the ledgers of the transactional books. We see this most clearly when the capitalist boom and bust cycles throws workers into the streets without any recourse for them to fall back on alternative opportunities, since the capitalist enterprise has cut off land-use except for capitalistic activity.

Let us summarize what this article has attempted to do: it has attempted to claim the Commons from the profiteers for the people. It has found a historical point of entry into the Anglo-American tradition before it was eclipsed by capitalism. It has put forth the normative claim that ALL members of a given community have a stake in the Commons; this is not a privilege offered by the profiteers or the government but a natural right based on a person's existence, and their existence cannot be taken away from them either by the government sector or the profiteers; and the Commons automatically attaches upon the formation of any community. The capitalist distributional model is unjust and unfair to all those that cannot command commodities under modern capitalism. That is to say that, modern capitalist conditions benefit a small section of society or community and excludes vast amounts of people from its benefits because it is exclusively based on the privileging of property ownership as an entrance point to the community. It generates a non-personal existence based on the non-personal commodity

58 Alan Trachtenberg, The InCorporation of America, (25th ann. ed. 2007) (1982). 
transaction. This yields a poor harvest as to the quality and nature of life for the human animal. It does not elevate the human animal but tries to extract its labor power and time on planet earth in exchange for wages. It is destructive of communities as it is the broader society in general. There is currently nothing on the horizon that will eliminate capitalism. However, by taking small steps to providing alternative means of existence to capitalism, we are hopefully firing the first shots towards its ultimate modification and demise. If it cannot be done in one swoop, then by taking small bites sizes out of it, until the day comes that other ways of Being can come into existence, that is not based on the cash-nexus and alternatives to the capitalist ways of Being can be seen on the horizon.

The article attempted to open-up the landscape to alternative use of space to the capitalist/utilitarian uses and to offer a way of life or revive ways of life that have been destroyed by markets and capitalism. It is an effort to give an equal opportunity to dispossessed people; by checking capitalism to only a portion of the life-cycle demands of the individual and not the totality-of-human existence and Being; that there be reserved to Being a portion of existence that is non-commercial, non-marketable, or on the selling block of capitalism---that some physical space remain open and available for the locals rather than gobbled up by the turbines of capitalist industrialization. That is, that some natural resources and spaces be offthe-market, not for sale. 
